\title{
Defeating cancer with antidepressants
}

\section{J Lieb}

127 Cumberland Road, Burlington, Vermont 05408, USA 8026584909

\begin{abstract}
Prostaglandins are ephemeral, infinitesimal signallers self-regulating every cell in the body, including those sub-serving mood and immunity. At first, they were perceived as a master switch, but now are believed to regulate every component of cellular micro-anatomy and physiology, including those of the organelles, cytoskeleton, proteins, enzymes, nucleic acids and mitochondria. Prostaglandins are responsible, paradoxically, for cell function and dysfunction. Excessive prostaglandin synthesis depresses immune function and may induce cancer. An ideal anti-cancer agent would inhibit prostaglandins in such a manner as to shut down the pathogenesis of cancer. In this paper, I will show that antidepressants have such properties.
\end{abstract}

Published: 21/08/2008

Received: 10/06/2008

ecancer 2008, 2:88 DOI: 10.3332/ecancer.2008.88

Copyright: (c) the authors; licensee ecancermedicalscience. This is an Open Access article distributed under the terms of the Creative Commons Attribution License (http://creativecommons.org/licenses/by/2.0), which permits unrestricted use, distribution, and reproduction in any medium, provided the original work is properly cited.

Competing Interests: The authors have declared that no competing interests exist.

Correspondence to J Lieb. Email: julianlieb@aol.com 


\section{The anti-prostaglandin, immunostimulating and antimicrobial properties of lithium and antidepressants}

Depression predisposes us to, among other things, infection, cancer, osteoporosis, and neurodegenerative, cardiovascular and auto-immune disorders [1,2]. Excessive syntheses of prostaglandins is incriminated in all of these [1,2]. Lithium and antidepressants have potent anti-prostaglandin, immunostimulating and antimicrobial properties, and antidepressants have the paradoxical ability to mitigate, reverse or induce auto-immunity $[1,2]$.

When synthesized excessively, prostaglandin E2 depresses cellular and humoral immunity, allowing pathogens to replicate 3. Prostaglandins regulate the physiology, immunity, replication and toxicity of micro-organisms and the resistance of their hosts [1-4]. Failure of non-steroidal anti-inflammatory drugs in infections led to the conclusion that inhibiting prostaglandins has limited value in that field. The prostaglandin-inhibiting properties of lithium and antidepressants have been neglected [5-10], along with their unique immunopotentiating and antimicrobial actions [2]. In the early 1950s, clinicians observed that patients treated for tuberculosis with the monoamine oxidase inhibitors isoniazid and iproniazid had an elevation of mood and energy. It was also observed that monoamine oxidase inhibitors have dual anti-tuberculosis and antidepressant properties failed to impact the pharmacology of infectious disorders. Remission of such manifestations of viral infections as sinusitis, sinobronchitis, frequent colds, sore throats, cold sores and genital herpes in patients taking lithium carbonate has been reported [11-13]. The polymorphonuclear leukocytes of a 29-year-old woman with eczema and recurrent staphylococcal and streptococcal skin infections were unresponsive to standard chemotactic stimuli. In vitro addition of lithium to her polymorphonuclear preparations restored their chemotactic response. After receiving lithium carbonate, $1 \mathrm{~g} / \mathrm{d}$ for five weeks, she became free of infection and relapsed when lithium was withdrawn [14]. Lithium chloride prevents replication of type 1 and 2 herpes virus in cell culture [15] and augments several in vitro immune reactions [16].

Monoamine oxidase inhibitors can reverse tuberculosis, aphthous ulcers, cold sores, genital herpes, upper respiratory tract infections and plantar warts [17-19]. Tricyclic antidepressants can reverse aphthous ulcers [20], reduce the frequency of recurrences of shingles $[1,2]$, remit the pain of this disorder [1,2], prevent post-herpetic neuralgia [1,2], destroy leishmania minor and major in vitro [21], and inhibit in vitro growth of the intestinal parasite giardia lamblia [22]. Tricyclic antidepressants have anti-malarial properties: they enhance in vitro susceptibility of Plasmodium falciparum to chloroquine and are lethal in vitro against Trypanasoma parasites [23-27]. Selective serotonin re-uptake inhibitors can destroy such fungi in vitro as Candida and Aspergillus [28], reverse recurrent vulvovaginal candidiasis in vivo [29], have anti-microbial activity [30] and are synergistic when combined with antibiotics [31].

Impaired lymphocyte function reduced natural killer cell activity, reduced lymphocyte responses to mitogens and decreased natural killer cell populations have been demonstrated in depressives $[1,2,32,33]$. Tricyclic antidepressants augment natural killer cell activity in vivo and in vitro [34] and the monoamine oxidase inhibitor tranylcypromine enhances defective cell-mediated immunity [35]. As lithium and antidepressants have immunopotentiating properties, they are effective against a wide range of micro-organisms. Evidence to date shows that while lithium has antiviral and antibacterial properties, antidepressants have antiviral, antibacterial, antiparasitic and fungicidal properties. Response of infection to lithium and antidepressants mirrors that of response to depression, with subjects responding selectively to antidepressants or lithium; antidepressants are highly specific and humans remarkably variable. Response of depression and infection to lithium or an antidepressant is usually simultaneous, suggesting that the central actions of the drugs are important. While antivirals are not necessarily immunostimulants, lithium and antidepressants are invariably antivirals. If antidepressants double as antibiotics, it would not be surprising if antibiotics doubled as antidepressants. Many antibiotics, among them clarithromycin, erythromycin, amoxacillin and ciprofloxacin, can elevate mood to the level of hypomania or mania [36].

\section{Prostglandins in carcinogenesis}

Among the mechanisms of carcinogenesis are up-regulation of cyclo-oxygenase, oncogene synthesis and expression, viral activation, signal disruption, accelerated cell replication, failed apoptosis, tumour initiation and promotion, angiogenesis, metastasis, immunosuppression, auto-immunity and activation of mitochondria. All fall within the orbit of prostaglandins and their forming enzymes. In 1968, Williams reported high levels of prostaglandins in the thyroid and plasma of patients with 
medullary cancer of the thyroid [37]. In 1976, Goodwin reported excessive synthesis of prostaglandin E2 in suppressor T-cells of patients with Hodgkin's disease [38]. Numerous studies have confirmed elevated levels of prostaglandins in solid tumours and in the immune cells and body fluids of cancer patients $[39,40]$. The isolation of such isoforms of cyclo-oxygenase as COX-2 [41], and the synthesis of selective COX-2 inhibitors has stimulated research into the expression of this isoform in cancer and its role in apoptosis. COX-2 is up-regulated in such cancers as those of the head and neck, breast, lung, pancreas, bladder, cervix, prostate and mesothelium [41-43]. In population studies, chronic use of such prostaglandin inhibitors as aspirin and ibuprofen has reduced the risk of colon cancer by as much as $40 \%$ [44].

Armato and Andreis showed that arachidonic acid and prostaglandins $\mathrm{F} 1$ alpha and F2 alpha stimulate the DNAsynthetic and mitotic activities of hepatocytes [45]. Goodlad has reported that the increase in gastric mucosal mass induced by misoprostol in the stomach of dogs is due to increased cell production. The increase in mucosal mass was the result of a dramatic increase in the foveolar surface mucous cells [46], other studies show a paradoxical, inhibitory effect of prostaglandins on DNA synthesis [47]. Prostaglandins and their synthesizing enzymes are key factors in many signalling events, and disruptions of signalling pathways have been incriminated in many cancers.

In her pioneering studies, Karmali [48,49] showed that increased thromboxane formation in human breast cancer specimens is associated with three clinical variables: tumour size, axillary lymph node metastases and distant metastases. The mechanisms by which prostaglandins and thromboxanes induce metastasis include induction of proteolytic enzyme production, neovascularization and subversion of the immune response. The initiation of metastasis is thought to involve the adherence of circulating tumour cells to endothelial cells or to basement membranes. Prostaglandins and thromboxanes play a role in adherence [49,50], with local thromboxane concentrations possibly determining the sites of metastasis [51]. Immunosuppression is a cause and effect of cancer. Increase in prostaglandins at the primary tumour focus may block surveillance by the immune system, while an increase in plasma prostaglandins may contribute to the suppressive environment for lymphocyte function [52].

In a paradoxical counterpoint to immunosuppression, numerous autoimmune phenomena are reported in patients with cancer [53]. Malignant tumours are diagnosed with increased frequency in patients with such autoimmune disorders as pemphigus,
Myasthenia gravis and the Eaton-Lambert syndrome [54,55]. The paraneoplastic syndrome includes a variety of neurological, haematological, metabolic, cardiovascular and dermatological disorders, in all of which prostaglandins have been incriminated $[55,56]$. As monoamine oxidase inhibitors, originally used in the treatment of tuberculosis, have potent antiviral and immunostimulating properties, it is not surprising that one of them, Matulane (procarbazine), is effective in treating stage 111 and 1V Hodgkin's disease.

\section{Depression: A precursor of cancer}

In the Ward Jones lecture given at Manchester University in 1957, Sir Heneage Ogilvie commented, 'I have slowly come to frame in my mind an aphorism that can never be stated as such, because no statistics can be advanced to support it: "The happy man never gets cancer" ... The instances where the first recognisable onset of cancer has followed almost immediately on some disaster, bereavement, the breakup of a relationship, a financial crisis, or an accident are so numerous that they suggest that some controlling force that has hitherto kept the outbreak ... in check has been removed' [57]. In 1998, Penninx et $a$ at at the National Institute of Aging provided compelling data for Ogilvie's hypothesis: chronically depressed people over the age of 70 are $88 \%$ more likely to develop cancer and twice as likely to die of it than their mellow peers [58].

\section{Antineoplastic properties of antidepressants in vitro}

Many studies show that antidepressants have potent anticancer properties, both in vitro and in vivo, with regard to various antidepressants, mechanisms of action and cancer cell types [59-78]. Irrespective of their putative mechanism of action, the antidepressants destroyed the cells or arrested their proliferation [59-78]. Hydroxyprostaglandin dehydrogenase is the primary prostaglandin-degrading enzyme, highly expressed in normal colon mucosa but lost in human colon cancers $[79,80]$. Lack of this enzyme promotes the earliest steps of growth of benign as well as malignant colon tumours $[79,80]$. When this enzyme was first characterized, every agent tested in the hope of stimulating it either had no effect or inhibited it. Eventually Mak and Chen showed that amitriptyline and imipramine powerfully activate the enzyme in mice, especially the kidney enzyme, with more than a thousand-fold activation by amitriptyline. Amitriptyline and imipramine had potent activating effects on this enzyme in the brain [81]. 


\section{Mitochondria, prostaglandins and antidepressants}

Mitochondria are tiny organelles that supply cellular energy and are involved in signalling, cellular differentiation, control of the cell cycle, growth and programmed cell death. The cells of malignant gliomas of the brain, and small and non-small cell cancers of the lung, tend to repair DNA-breaks caused by radiation and chemotherapy. In an effort to accomplish cell death by an alternative method, investigators are targeting mitochondria. Small molecule agents known as 'mitocans' are able to enter tumour cell mitochondria, reduce oxygen consumption, and activate mechanisms leading to cell death. Agents that can destroy cancer cells in this manner, while leaving normal cells intact, notably include antidepressants [8284]. Laboratory experiments using this approach on various cancer cells, including those of gliomas, are encouraging $[65,66]$. It goes without saying that prostaglandins are intermediaries between mitocans and mitochondria [85-87].

\section{Antineoplastic properties of antidepressants in vivo}

A woman suffering from major depression and advanced liver cancer (hepatoma) was treated with psychotherapy, the antidepressant fluvoxamine (Luvox), glycyrrhizin acid and dehydroepiandrosterone (DHEA). Various indices of defective immune function normalized, and her liver function tests improved. At follow-up two-and-a-half years later, she was well and symptom free [88]. In 1990, a 60-year-old woman had a mastectomy for inflammatory breast cancer, followed by excision of infiltration of the chest wall. She was given a prognosis of less than a year. I treated her with various antidepressants, and when relocating in 2003 she was in apparent good health.

A middle-aged man had a two-year history of recurrent glioblastoma multiforme of the cerebellum, resistant to all conventional therapies. Within a week of starting sertraline, he noticed an appreciable reduction in tremor and ataxia. After taking the antidepressant for three weeks, he was virtually free of these symptoms.

\section{Discussion}

It would seem that antidepressants have the potential to arrest, prevent, reverse and palliate cancer. Short of that they have many other uses in cancer care. Antidepressants can reduce the severity and frequency of hot flashes in patients treated with chemotherapy for breast cancer, and venlafaxine (Effexor), and remit acute neurosensory symptoms secondary to oxaliplatin chemotherapy [89]. The monoamine oxidase inhibitors deprenyl and clorgyline protect nonmalignant human cells from ionising radiation and chemotherapy toxicity [90], and such antidepressants as nefadazone are capable of reversing chemotherapy-induced vomiting [91].

As the response to antidepressants is highly specific, many patients require multiple trials before responding. Some subjects are refractory to all antidepressants, and some relapse due to tachyphylaxis [92]. Prostaglandins are capable of paradoxically inducing pro- and anti-cancer actions. The omnipresence of paradox warns that antidepressants are capable of initiating or accelerating cancer. Maintaining an index of suspicion, close clinical observation and limiting the duration of drug trials can mitigate such paradox. Epidemiological studies have failed to confirm the suspicion that antidepressants may induce breast cancer [93]. However, breast cancer has been reported in three men, taking selective serotonin re-uptake inhibitors [94].

Wherever prostaglandin-synthesizing enzymes convert arachidonic acid or phospholipids to prostaglandins, there are possible sites of action of antidepressants. By maintaining these enzymes within physiological limits, antidepressants shut down the mechanisms of carcinogenesis. Considerable evidence now shows that antidepressants are cytotoxic and cytostatic; convert multidrug resistant cells to sensitive and protect nonmalignant cells from ionizing radiation and chemotherapy [95]. While lithium has immunostimulating and anti-microbial properties, there is little evidence for its possible antineoplastic actions. Antidepressants have potent analgesic properties alone or as potentiators of narcotics, and they enhance sleep, appetite and occasionally energy. Their immunostimulating and anti-microbial properties are relevant to infection secondary to chemotherapy or radiation. Alleviation of anxiety, depression, recrimination and remorse by antidepressants can be very beneficial. 


\section{References}

1. Lieb J (1983) Remission of rheumatoid arthritis and other disorders of immunity in patients taking with monoamine oxidase inhibitors Int J Immunopharmac 34 353-7 PMID 6629596 doi:10.1016/0192-0561(83)90039-5

2. Lieb J (2004) The immunostimulating and antimicrobial properties of lithium and antidepressants J Infection 492 88-93 PMID 15236914 doi: 10.1016/j.jinf.2004.03.006

3. Bankhurst $A$ (1982) The modulation of human natural killer cell activity by prostaglandins J Clin Lab Immunol 72 8591 PMID 6951051

4. Lieb J (2001) Antidepressants, eicosanoids and the prevention and treatment of cancer Prostaglandins Leukot Essent Fatty Acids 65 5\&6 233-9 PMID 11993714 doi:10.1054/plef.2001.0319

5. Horrobin DF and Manku MS (1977) Roles of prostaglandins suggested by the prostaglandin agonist/antagonist actions of local anaesthetic, anti-arrhythmic, anti-malarial, tricyclic anti-depressant and methyl xanthine compounds. Effects on membranes and on nucleic acid function Effect Hypotheses 32 71-86 PMID 197384 doi:10.1016/03069877(77)90057-3

6. Lee R (1974) The influence of psychotropic drugs on prostaglandin biosynthesis. Prostaglandins 51 63-8 PMID 4816720 doi: 10.1016/S0090-6980(74)80132-2

7. Hong S, Carty T and Deykin D (1980) Tranylcypromine and 15-hydroperoxyarachidonate affect arachidonic acid release in addition to inhibition of prostacyclin synthesis in calf aortic endothelial cells J Biol Chem 25520 9538-40 PMID 6776101

8. Manku MS and Horrobin DF (1976) Chloroquine, quinine, procaine, quinidine and clomipramine are prostaglandin agonists and antagonists Prostaglandins 125 789-801

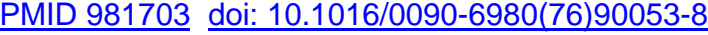

9. Yaron I, Shirazi I, Judovich R et al (1999) Fluoxetine and amitriptyline inhibit nitric oxide, prostaglandin $\mathrm{E} 2$, and hyaluronic acid production in human synovial cells and synovial tissue cultures Arthritis and Rheumatism 4212 2561-8 PMID 10616001 doi: 10.1002/15290131(199912)42:12<2561::AID-ANR8>3.0.CO;2-U

10. Ellis E, Rosenblum W, Birkle D et al (1982) Lowering the brain levels of the depressant prostaglandin D2 by the antidepressant tranylcypromine Biochem Pharmacol 319 1783-4 PMID 7104040 doi: 10.1016/0006-2952(82)90685 2

11. Lieb J (1981) Remission of herpes virus infection and immunopotentiation with lithium carbonate: Inhibition of prostaglandin E1 synthesis by lithium may explain its antiviral, immunopotentiating, and antimanic properties Proc 3rd World Congress of Biological Psychiatry
(Stockholm) Biol Psych ed C Perris, G Struwe, B Jansson pp 695-8.

12. Hansell N (1990) Manic illness presenting with physical symptoms Am J Psychiatry 14711 1575-6 PMID 2221182

13. Amsterdam J, Maislin G and Rybakowski J (1990) A possible antiviral action of lithium carbonate in herpes simplex virus infections Biol Psychiatry 274 447-53 PMID 2155671 doi: 10.1016/0006-3223(90)90555-G

14. Shenkman L, Borkowsky W and Shopsin B (1980) Lithium as an immunologic adjuvant Med Hypotheses 6 1 $1-6$ PMID 6247627 doi: 10.1016/0306-9877(80)90025-0

15. Skinner G, Hartley C, Buchan A et al (1980) The effect of lithium chloride on the replication of herpes simplex virus Med Microbiol Immunol 1682 139-48 PMID 6256617 doi: 10.1007/BF02121762

16. Weetman A, McGregor A, Lazarua J et al (1982) The enhancement of immunoglobulin synthesis by human lymphocytes with lithium Clin Immunol 22 3 400-7 PMID $\underline{6286192}$

17. Lieb J (1984) Invisible Antivirals Int J Immunopharmacol 16 1 1-5 PMID 8150552 doi:10.1016/0192-0561(94)90113-9

18. Rosenthal S and Fitch W (1984) The antiherpetic effects of phenelzine J Clin Psychopharmacol 72119 PMID 3584520

19. Lofft J (1985) MAO inhibitors Psychiatry Times (November)

20. Yeragani V, Phol R, Keshavan M et al (1987) Are tricyclic antidepressants effective for aphthous ulcers? J Clin Psychiatry 486256 PMID 3584086

21. Zilberstein D and Dwyer D (1984) Antidepressants cause lethal disruption of membrane function in the human protozoan parasite leishmania Science 2264677 977-9. PMID 6505677 doi: 10.1126/science.6505677

22. Weinbach, E, Costa J, Wieder S (1985) Antidepressant drugs suppress growth of the human pathogenic protozoan giardia Iamblia Res Commun Chem Pathol Pharmacol 471 145-8 PMID 3983467

23. Bitonti A, Sjoerdsma A, McCann P et al (1988) Reversal of chloroquine resistance in malaria parasite plasmodium falciparum by desipramine Science 24248883 1301-3 PMID 3057629 doi:10.1126/science.3057629

24. Salama A and Facer C (1990) Desipramine reversal of chloroquine resistance in wild isolates of plasmodium falciparum Lancet $3358682 \quad 164-5$ PMID 1967451 doi:10.1016/0140-6736(90)90034-3

25. Dutta P, Pinto J and Rivlin R (1990) Antimalarial properties of imipramine and amitriptyline J Protozool 37 1 54-8 PMID 2406432

26. Coutaux A, Mooney J and Wirth D (1994) Neuronal monoamine reuptake inhibitors enhance in vitro 
susceptibility to chloroquine in resistant Plasmodium falciparum Antimicrob Agents Chemother 386 1419-21 PMID 8092848

27. Doyle $P$ and Weinbach $E$ (1989) The activity of tricyclic antidepressant drugs against Trypanosoma cruzi Exp Parasitol 682 230-4 PMID 2647509 doi: 10.1016/00144894(89)90102-1

28. Lass-Flörl C, Dierich MP, Fuchs D et al (1989) Antifungal activity against Candida species by the selective serotonin reuptake inhibitor sertraline Clin Infect Dis 3312 E135E136 PMID 11700578 doi: 10.1086/324589

29. Lass-Flörl C, Dierich M, Fuchs D et al (2001) Antifungal properties of selective serotonin reuptake inhibitors against aspergillus species in vitro $\mathrm{J}$ Antimicrob Chemother 486 775-9 PMID 11733460 doi: 10.1093/jac/48.6.775

30. Munoz-Bellido J, Munoz-Criado S and Garcia-Rodriguez J (2000) Antimicrobial activity of psychotropic drugs: selective serotonin reuptake inhibitors Int $\mathrm{J}$ Antimicrob Agents 143 177-80 PMID 10773485 doi: 10.1016/S09248579(99)00154-5

31. Munoz-Bellido J, Munoz-Criado S and Garcia-Rodriguez J (1996) In-vitro activity of psychiatric drugs against Corynebacterium unrealyticum (Corynebacterium group D2) J Antimicrob Chemother 375 1005-9 PMID 8737151 doi: $10.1093 / j a c / 37.5 .1005$

32. Calabrese J, Skwerer R, Barna B et al (1984) Depression, immunocompetence, and prostaglandins of the $E$ series Psychiat Res 17 41-7 doi:10.1016/0165-1781(86)90040-5

33. Evans DL, Pedersen CA and Folds JD (1984) Major depression and immunity: Preliminary evidence of decreased natural killer cell populations Prog NeurolPsychopharmacol Biol Psychiat 12 739-74 doi: 10.1016/0278-5846(88)90019-X

34. Frank M, Hendricks S, Johnson D et al (1999) Antidepressants augments natural killer cell activity: in vivo and in vitro Neuropsychobiology $391018-24$ PMID $\underline{9892855}$ doi: $10.1159 / 000026555$

35. Leung K, Mihich E (1980) Prostaglandin modulation of development of cell-mediated immunity in culture Nature 288 597-600 PMID 7003398 doi: 10.1038/288597a0

36. Abouesh A, Stone C and Hobbs W (2002) Antimicrobialinduced mania (antibiomania): a review of spontaneous reports J Clin Psychopharmacol 22 1 71-81 PMID 11799346 doi: 10.1097/00004714-200202000-00012

37. Williams ED, Karim SMM and Sandler M (1968) Prostaglandin secretion by medullary carcinoma of the thyroid Lancet 1 22-3 PMID 4169067 doi:10.1016/S0140$\underline{6736(68) 90010-X}$
38. Goodwin JS, Murphy S, Bankhurst AD et al (1977) Prostaglandin-producing suppressor cells in Hodgkin's disease New Engl J Med 297 963-8. PMID 409950

39. Bennett A, Carter RL, Stamford IF, Tanner NSB (1980) Prostaglandin-like material extracted from squamous carcinomas of the head and neck $\mathrm{Br} J$ Cancer 41 204-9 PMID 7370160

40. Kokoglu E, Tuter Y, Sandikci KS et al (1998) Prostaglandin E2 levels in human brain tumor tissues and arachidonic acid levels in the plasma membrane of human brain tumors Cancer Lett 132 1-2 17-21 PMID 10397448 doi: 10.1016/S0304-3835(98)00127-X

41. Chan G, Boyle JO, Yang EK, Zhang F, Sacks PG et al (1999) Cyclooxygenase-2 expression is up-regulated in squamous cell carcinoma of the head and neck Cancer Res 595 991-4 PMID 10070952

42. Molina MA, Sitja-Arnau M, Lemoine MG, Frazier ML and Sinicrope FA (1999) Increased cyclooxygenase-2 expression in human pancreatic carcinomas and cell lines: growth inhibition by non-steroidal anti-inflammatory drugs Cancer Res 5917 4356-62 PMID 10485483

43. Watkins DN, Lenzo JC, Segal A, Garlepp MJ and Thompson PJ (1999) Expression and localization of cyclooxygenase isoforms in non-small cell lung cancer Eur Respir J 142 412-8 doi:10.1034/j.1399-3003.1999.14b28.x

44. Thun MJ, Namboordiri MM and Heath CW Jr (1991) Aspirin use and reduced risk of fatal colon cancer $N$ Engl J Med 325 1593-6 PMID 1669840

45. Armato $U$ and Andreis PG (1983) Prostaglandins of the $F$ series are extremely powerful growth factors for primary neonatal rat hepatocytes Life Sci 33 1745-55 PMID $\underline{6645776}$ doi: 10.1016/0024-3205(83)90681-1

46. Goodlad RA, Madgwick AJ, Moffatt MR et al (1990) Prostaglandins and the dog stomach: Effects of misoprostol on the proportion of mucosa to muscle and on the proportion of different epithelial type cells Digestion 45 212-6 PMID 2119321 doi:10.1159/000200248

47. Hughes-Fulford M (1997) Prostaglandin regulation of gene expression and growth in normal and malignant tissues $A d v$ Exp Med Biol 400A 269-78 PMID 9547568

48. Karmali RA, Sarkar NH, Emerson W and Good RA (1982) Prostaglandin regulation of murine mammary tumor virus production: a basis for some of the glucocorticoid and prolactin actions on mammary tumor cell cultures Prostaglandins Leukot Med 9 641-55 doi: 10.1016/02621746(82)90021-X

49. Karmali RA, Welt S, Thaler HT and Lefevre F (1983) Prostaglandins in breast cancer: relationship to disease stage and hormone status $\mathrm{Br} \mathrm{J}$ Cancer 48 689-96 PMID $\underline{6416285}$ 
50. Tisdale MJ (1983) Role of prostaglandins in metastatic dissemination of cancer: minireview on cancer research Expl Cell Biol 51 250-6

51. Nanji AA (1979) Thromboxane synthase and organ preference for metastases New Eng J Med 329 138-9 $\underline{\text { PMID } 8510699}$

52. Dilman VR (1977) Metabolic immunosuppression which increases the risk of cancer Lancet 2 1207-9 PMID 73905 doi:10.1016/S0140-6736(77)90442-1

53. Houssiau FA, Kirkove C, Asherson RA, Hughes GRV and Timothy AR (1977) Malignant lymphoma in systemic rheumatic diseases. A report of five cases Clin Exp Rheumatol 9 515-8 PMID 1954702

54. Sela $O$ and Shoenfeld $Y$ (1988) Cancer and autoimmune diseases Semin Arthritis Rheum 18 77-87 PMID 3064306 doi: 10.1016/0049-0172(88)90001-7

55. Isomaki HA, Hakulinen T and Joutsenlahti U (1978) Excess risk of lymphomas, leukemia and myeloma in patients with rheumatoid arthritis J Chronic Dis 31 691-6 PMID 730824 doi: 10.1016/0021-9681(78)90071-1

56. Minna JD and Bunn PA Jr (1982) Paraneoplastic syndromes Principles and practices of oncology ed VT Devita et al (Philadelphia: Lippincott) 1476-517

57. Ogilvie H (1957) The Human Heritage Lancet 273 35-40 PMID 13450323

58. Penninx B.W, Guralnik J.M, Pahor M et al (1998) Chronically depressed mood and cancer risk in older persons J Natl Cancer Inst 9024 1888-93 PMID 9862626 doi: 10.1093/jnci/90.24.1888

59. Levkovitz Y, Gil-Ad I, Zeidich E et al (2005) Differential induction of apoptosis by antidepressants in glioma and neuroblastoma cell lines: evidence for $\mathrm{p}$-c-Jun, cytochrome $\mathrm{C}$, and caspase3 involvement $\mathrm{J} \mathrm{Mol} \mathrm{Neurosci} 27129-42$ PMID 16055945 doi: 10.1385/JMN:27:1:029

60. Toki S, Donati RJ and Rasenick MM (1999) Treatment of C6 glioma cells and rats with antidepressant drugs increases the detergent extraction of $G$ (s alpha) from plasma membrane $\mathrm{J}$ Neurochem $73 \quad 3 \quad$ 1114-20 PMID 10461902 doi: 10.1046/j.1471-4159.1999.0731114.x

61. Hsu SS, Huang CJ, Chen JS et al (2004) Effect of nortriptyline on intracellular $\mathrm{Ca}+$ handling and proliferation in human osteosarcoma cells Basic Clin Pharmacol Toxicol 953 124-30 PMID 15447736

62. Hsu SS, Chen WC, Lo YK et al (2004) Effect of the antidepressant maprotiline on $\mathrm{Ca}+$ movement and proliferation in human prostate cell lines Clin Exp Pharmacol Physiol $317444-9$ PMID 15236632 doi: 10.1111/j.1440-1681.2004.04024.x
63. Serafeim A, Holder MJ, Grafton G et al (2003) Selective serotonin reuptake inhibitors directly signal for apoptosis in biopsy-like Burkitt lymphoma cells Blood 1018 3212-9 PMID 12515726 doi: 10.1182/blood-2002-07-2044

64. Freire-Garabal M, Rey-Mendez M, Garcia-Vallejo LA et al (2004) Effects of nefadazone on the development of experimentally induced tumors in stressed rodents Psychopharmacology (Berl) $176 \quad 3-4 \quad 233-8 \quad \underline{\text { PMID }}$ 15164159 doi: $10.1007 / \mathrm{s} 00213-004-1909-4$

65. Freire-Garabal M, Nunez MJ, Pereiro D et al (1998) Effects of fluoxetine on the development of lung metastases induced by operative stress in rats Life Sci 632 PL31-8 PMID 9674952 doi:10.1016/S0024-3205(98)00253-7

66. Honda T, Favalaro FG Jr, Kjanosik T et al (2003) Efficient synthesis of (-) and (+)-tricyclic compounds with enone functionalities in rings $A$ and $C$. A novel class of orally active anti-inflammatory and chemopreventive agents Org Biomol Chem 124 4384-91 PMID 14685310 doi: 10.1039/b307491a

67. Arimochi $\mathrm{H}$ and Morita $\mathrm{K}$ (2006) Characterization of cytotoxic actions of tricyclic antidepressants on human HT29 colon carcinoma cells Eur J Pharmacol 541 1-2 1723 PMID 16753142 doi: 10.1016/j.ejphar.2006.04.053

68. Daley E, Wilkie D, Loesch A and Hargreaves IP (2005) Kendall DA, Pilkington GJ, Bates TE Chlorimipramine: a novel anticancer agent with a mitochondrial target Biochem Biophys Res Commun 3282 623-32 PMID 15694394 doi: 10.1016/j.bbrc.2005.01.028

69. Ballin A, Gershon V, Brener J, Weizman A and Meytes D (1997) The antidepressant fluvoxamine increases natural killer cell counts in cancer patients Isr J Med Sci 3311 720-3 PMID 9434807

70. Varga A, Nugel H, Baehr $R$ et al (1997) Reversal of multidrug resistance by amitriptyline in vitro Anticancer Res 1 209-11 PMID 8615610

71. Sauter C (1989) Cytostatic activity of commonly used tricyclic antidepressants Oncology $46 \quad 3 \quad 155-7 \quad$ PMID 2717124 doi: $10.1159 / 000226705$

72. Spanova A, Kovaru H, Lisa V, Lukasova $E$ and Rittich B (1997) Estimation of apoptosis in C6 glioma cells treated with antidepressants Physiol Res $46 \quad 2$ 161-4 PMID $\underline{9727508}$

73. Snyder SW, Egorin MJ, Zuhowski EG, Schimpff EC and Callery PS (1990) Effects of the monoamine oxidase inhibitor, tranylcypromine, on induction of HL60 differentiation by hexamethylene bisacetamide and $\mathrm{N}$ acetyl-1.6-diaminohexane Cancer Commun 27 231-61 PMID 2378784

74. Volpe DA, Ellison CD, Parchment RE, Grieshaber CK and Faustino PJ (2003) Effects of amitriptyline and fluoxetine 
upon the in vitro proliferation of tumor cell lines $J$ Exp Ther Oncol 34 169-84 PMID 14567288 doi: 10.1046/i.13594117.2003.01091.x

75. Seymour $\mathrm{CB}$, Mothersill $\mathrm{C}$, Mooney R, Moriarty M and Tipton KF (2003) Monoamine oxidase inhibitors I-deprenyl and clorgyline protect nonmalignant human cells from ionizing radiation and chemotherapy toxicity $\mathrm{Br} J$ Cancer 89 10 1979-86 PMID 14612913 doi: 10.1038/sj.bjc.6601361

76. Xia Z, Bergstrand A, DePierre JW and Nassberger L (1999) The antidepressants imipramine, clomipramine and citalopram induce apoptosis in human acute myeloid leukemia HL-60 cells via caspase 3 activation $\mathrm{J}$ Biochem Mol Toxicol $13 \quad 6 \quad 338-47$ PMID $10487422 \quad$ doi: 10.1002/(SICl)1099-0461(1999)13:6<338::AID-JBT8>3.0. $\underline{\mathrm{CO} ; 2-7}$

77. Nordenberg J, Fenig E, Landau M, Weizman R and Weizman A (1999) Effects of psychotropic drugs on cell proliferation and differentiation Biochem Pharmacol 588 1229-36 doi: 10.1016/S0006-2952(99)00156-2

78. Rosetti M, Frasnelli M, Tesei A, Zoli W and Conti M (2006) Cytotoxicity of different serotonin reuptake inhibitors (SSRIs) against cancer cells J Exp Ther Oncol 61 23-9. PMID 17228521

79. Yan M, Rerko RM, Platzer $P$ et al (2004) 15Hydroxyprostaglandin dehydrogenase, a COX-2 oncogene antagonist, is a TGF-beta-induced suppressor of human gastrointestinal cancers Proc Natl Acad Sci USA 10150 17468 PMID 15574495 doi: 10.1073/pnas.0406142101

80. Myung SJ, Rerko RM, Yan $M$ et al (2006) 15Hydroxyprostaglandin dehydrogenase is an in vivo suppressor of colon tumorigenesis Proc Natl Acad Sci 103 32 12098-102 PMID 16880406 doi: 10.1073/pnas. $\underline{0603235103}$

81. Mak O and Chen S (1986) Effects of two antidepressant drugs, imipramine and amitriptyline on the enzyme activity of 15-hydroxyprostaglandin dehydrogenase purified from brain, lung, liver and kidney of mouse Prog Lipid Res 2525 153-5 doi:10.1016/0163-7827(86)90030-5

82. Neuzil J, Wang XF, Dong LF, Low P and Ralph SJ (2006) Molecular mechanism of mitocan-induced apoptosis in cancer cells epitomizes the multiple roles of reactive oxygen species and Bcl family proteins FEBS Lett 58022 5125-9 PMID 16979626 doi: 10.1016/i.febslet.2006.05. $\underline{072}$

83. Pilkington GJ, Parker $K$ and Murray SA (2008) Approaches to mitochondrially mediated cancer therapy Semin Cancer Biol 183 226-35 PMID 18203619 doi: 10.1016/j.semcancer.2007.12.006

84. Arimochi $\mathrm{H}$ and Morita $\mathrm{K}$ (2008) Desipramine induces apoptotic cell death through nonmitochondrial and mitochondrial pathways in different types of human colon carcinoma cells Pharmacology 812 164-72 PMID 18025841 doi: $10.1159 / 000111144$

85. Martinez B, Perez-Castillo A and Santos A (2005) The mitochondrial respiratory complex 1 is a target for 15deoxy-delta12, 14-prostaglandin $\mathbf{J 2}$ action J Lipid Res 464 736-43 PMID 15654126 doi: 10.1194/j|r.M400392JLR200

86. Lender A, Shiva S, Levenson AL, Oh JY, Zaragoza C, Johnson MS and Darley-Usmar VM (2006) Induction of the permeability transition and cytochrome c release by 15-deoxy-Delta12-prostaglandin $\mathrm{J} 2$ in mitochondria Biochem J 394 pt 1 185-95 PMID 16268779

87. Nencioni A, Lauber K, Grunebach F, Van Pariis, Denzlinger C, Wesselborg S and Brossart P (2003) Cyclopentenone prostaglandins induce the mitochondrial lymphocyte apoptosis pathway independent of external death receptor signaling $\mathrm{J}$ Immunol $171 \quad 10$ 5148-56 PMID 14607914

88. Jozuka H, Jozuka E, Suzuki M, Takeuchi S and Takatsu Y (2003) Psycho-neuro-immunological treatment of hepatocellular carcinoma with major depression-a single case report Curr Med Res Opin 191 59-63 PMID 12661782 doi: $10.1185 / 030079902125001362$

89. Durand JP, Brezault C and Goldwasser F (2003) Protection against oxaliplatin acute neurosensory toxicity by venlafaxine Anticancer Drugs 146 423-5 doi: 10.1097/00001813-200307000-00006

90. Seymour CB, Mothersill C, Mooney R, Moriarty M and Tipton KF (2003) Monoamine oxidase inhibitors Ideprenyl and clorgyline protect nonmalignant human cells from ionising radiation and chemotherapy toxicity $\mathrm{Br} J$ Cancer 8910 1979-86 PMID 14612913 doi: 10.1038/sj.bjc. 6601361

91. Khouzam HR, Monteiro AJ and Gerken ME (1998) Remission of cancer chemotherapy-induced emesis during antidepressant therapy with nefadazone Psychosom Med 60 89-91 PMID 9492245

92. Lieb J and Balter A (1984) Antidepressant tachyphylaxis Med Hypoth 15 279 doi: 10.1016/0306-9877(84)90018-5

93. Cotterchio $M$, Kreiger N, Darlington $G$ and Steingart $A$ (2000) Antidepressant medication use and breast cancer risk Am J Epidemiol 15110 951-7 PMID 10853633

94. Wallace WA, Balsitis M and Harrison BJ (2001) Male breast neoplasia in association with selective serotonin re-uptake inhibitor therapy: a report of three cases Eur J Surg Oncol 274 429-31 PMID 11417992 doi: $\underline{10.1053 / e j s o .2000 .1066}$

95. Lieb J (2008) The multifaceted value of antidepressants in cancer therapeutics Eur J Cancer 44 172-4 PMID $\underline{18063359}$ doi: 10.1016/i.ejca.2007.11.006 